\title{
Minimum Inhibitory Concentration of Vancomycin to Methicillin Resistant Staphylococcus aureus at a tertiary care hospital in Sri Lanka
}

\author{
Nilanthi P Senanayake ${ }^{1}$, F S Sally ${ }^{2}$, Harshi Abeygunawardena ${ }^{3}$, M S Karunarathne ${ }^{3}$, Shirani Chandrasiri ${ }^{4}$ \\ ${ }^{1}$ Faculty of Medicine, Colombo, Sri Lanka \\ ${ }^{2}$ British College of Applied Science, Sri Lanka \\ ${ }^{3}$ Kotalawela Defense University, Sri Lanka \\ ${ }^{4}$ Colombo South Teaching Hospital, Sri Lanka
}

\author{
Article information \\ Total number of \\ Words 1908 \\ Tables 04 \\ Authors have no conflicts of interest to \\ declare
}

Keywords: MRSA, Vancomycin, Minimum Inhibitory Concentration

Date of submission: 18.11 .2018

Date of acceptance: 01.12.2019

Author responsible for correspondence:

Dr. N P Senanayake

Department of Microbiology

Faculty of Medicine

Colombo, Sri Lanka

Email: nilanthi@micro.cmb.ac.lk

https://orcid.org/0000-0002-6413-5559

DOI: http://doi.org/10.4038/cjms.v56i1.4942

\begin{abstract}
Background:

Methicillin Resistant Staphylococcus aureus (MRSA) has evolved as a serious threat to public health.
\end{abstract}

\section{Objectives:}

The objectives of the present study were to determine the antibiotics susceptibility patterns of $S$. aureus and the minimum inhibitory concentration (MIC) of vancomycin to MRSA isolated from different clinical samples at the Colombo South Teaching Hospital (CSTH) in Sri Lanka.

\section{Methodology:}

A total 72 isolates of $S$. aureus, obtained from different clinical samples at the CSTH, from January to May 2017 were included in the study. $S$. aureus isolates were identified by Gram stain, colony morphology, catalase, slide/tube coagulase tests. The antibiotic susceptibility tests were carried as per Clinical Laboratory Standards Institute (CLSI) guidelines. MRSA isolates were detected using the cefoxitin $(30 \mu \mathrm{g})$ disk diffusion test. Inducible clindamycin resistance $\left(\mathrm{MLS}_{\mathrm{B}} \mathrm{i}\right)$ was detected by the disk approximation (D test) test. The vancomycin MICs were determined by the E-test method with a 0.5 McFarland standard inoculum. The MIC clinical breakpoints were defined according to the CLSI guidelines (susceptible, $\leq 2 \mu \mathrm{g} / \mathrm{ml}$; intermediate, $4-8 \mu \mathrm{g} / \mathrm{ml}$; and resistant, $\geq 16$ $\mu \mathrm{g} / \mathrm{ml})$.

\section{Results:}

Of the $72 \mathrm{~S}$. aureus clinical isolates, 29 (40.2\%) were MRSA. Inducible clindamycin resistance was detected in $16 \%$ of the MRSA isolates. Minimum inhibitory concentrations of vancomycin to the isolates of MRSA ranged from $0.125 \mu \mathrm{g} / \mathrm{ml}$ to $2 \mu \mathrm{g} / \mathrm{ml}$.

\section{Conclusions:}

The rate of isolation of MRSA was high and it has emerged as a serious public health threat to Sri Lanka. The Minimum Inhibitory Concentration (MIC) of all the MRSA isolates were $\leq 2 \mu \mathrm{g} / \mathrm{ml}$. None of the MRSA isolates were found to be intermediate-sensitive or vancomycin resistant. Therefore, vancomycin can be used as the drug of choice for treatment of infections caused by MRSA. 


\section{Background}

Methicillin-resistant Staphylococcus aureus (MRSA) has been recognized as one of the major pathogens in both hospital and community settings[1]. The first case of MRSA was isolated way back in 1961[2]. Since then, there has been an escalating rate of infections caused by MRSA worldwide resulting in increased mortality and morbidity statistics[3]. Vancomycin is regarded as the drug of choice for the treatment of infections caused by MRSA[4-8]. The emergence of VISA and VRSA has been reported by many authors[9]. Further, there are some reported cases of treatment failure of the infections caused by MRSA having MIC of vancomycin just below cutoff value [10]. Till date, there is one VRSA that has been reported from Sri Lanka[11]. The increasing trends of decreased susceptibility of the strains of MRSA to vancomycin reported from a community study conducted in Sri Lanka, indicated the need of more research in the field[12]. High vancomycin MIC for MRSA which are susceptible to vancomycin may indicate the drug resistance to many antibiotics[13-14]. MRSA is resistant to entire classes of $\beta$-lactams including cephalosporins and carbapenems and has higher risk of development of resistance to quinolones, aminoglycosides and macrolides[15-16]. Methicillin resistance in $S$. aureus is mediated through an altered protein called low-affinity penicillin binding protein (PBP2a). PBP2a is encoded by mec A gene which is present in chromosomal mobile genetic element called Staphylococcal cassette chromosome mec (SCCmec)[13-18]. Due to possible association of MRSA with multiple antibiotic resistance and relatively difficult and higher cost of treatment, the accurate and rapid identification of MRSA is essential for management of the infections caused by this superbug[18]. The objectives of the present study were to determine the antibiotics susceptibility patterns of $S$. aureus and the minimum inhibitory concentration (MIC) of vancomycin to MRSA isolated from different clinical samples at the Colombo South Teaching Hospital (CSTH) in Sri Lanka.

\section{Methods}

A total 72 clinical isolates of $S$. aureus obtained from different clinical samples (pus/wound swabs, ear swabs, urine, sputum, tracheal aspirates, fluid aspirates and blood) received at the Department of Microbiology, CSTH were included as the study sample. This was a descriptive, cross sectional study and the study was conducted from January to May 2017.

Isolation and identification of $S$. aureus

The clinical samples were inoculated on blood and MacConkey agar and were incubated at $35^{\circ} \mathrm{C}$ to $37^{\circ} \mathrm{C}$ for 18 hours. The $S$. aureus clinical isolates were identified by Gram stain, colony morphology, catalase, slide/tube coagulase tests.

Detection of methicillin resistance

Detection of MRSA was performed by using cefoxitin disc $(30 \mu \mathrm{g})$. The isolates showing diameter of zone of inhibition of $\leq 21 \mathrm{~mm}$ were considered as methicillin resistant $S$. aureus (MRSA) while those with diameter of zone of inhibition of $\geq 22 \mathrm{~mm}$ were identified as methicillin sensitive $S$. aureus (MSSA).

Antibiotic susceptibility test

The antibiotic susceptibility tests were carried as per Clinical Laboratory Standards Institute (CLSI) guidelines. The antibiotic susceptibility tests were carried out for Erythromycin $(15 \mu \mathrm{g})$, Clindamycin $(2 \mu \mathrm{g}), \quad$ Ciprofloxacin $(5 \mu \mathrm{g})$, Gentamycin $\quad(10 \mu \mathrm{g}), \quad$ Trimethoprimsulfamethoxazole $(1.25 / 23.75 \mu \mathrm{g})$, Amikacin $(30 \mu \mathrm{g})$, Linezolid $(30 \mu \mathrm{g})$, Chloramphenicol $(30 \mu \mathrm{g})$, Tetracycline $(30 \mu \mathrm{g})$ and Penicillin G (10U).

\section{Detection of inducible clindamycin resistance}

The isolates that were resistant to erythromycin were further studied for inducible clindamycin resistance $\left(M L S_{B} \mathrm{i}\right)$ by the disk approximation (D test) test. Clindamycin and erythromycin disks were placed 15-26 mm apart from each other on the MHA plates. After 18 hours of incubation at $35^{\circ} \mathrm{C}-37^{\circ} \mathrm{C}$, plates were checked. Flattening of inhibition zone (D-shaped) around clindamycin was considered as inducible clindamycin resistance $\left(\mathrm{MLS}_{\mathrm{B}} \mathrm{i}\right)$. The isolates resistant to both erythromycin and clindamycin were defined as constitutive MLSB $\left(\mathrm{MLS}_{\mathrm{B}} \mathrm{c}\right)$ phenotype and isolates that were resistant to erythromycin and sensitive to clindamycin were defined as $\mathrm{MS}_{\mathrm{B}}$ phenotype.

Determination of minimum inhibitory concentration of vancomycin to MRSA

The vancomycin MICs of MRSA were determined by the E-test method with a 0.5 
McFarland standard inoculum. The different dilutions of vancomycin used were $0.016 \mu \mathrm{g} / \mathrm{ml}$ to $256 \mu \mathrm{g} / \mathrm{ml}$.

The MIC clinical breakpoints were defined according to the CLSI guidelines (susceptible, $\leq 2$ $\mu \mathrm{g} / \mathrm{ml}$; intermediate, 4 to $8 \mu \mathrm{g} / \mathrm{ml}$; and resistant, $\geq 16 \mu \mathrm{g} / \mathrm{ml}$ ).

\section{Results}

Of the 72 S. aureus clinical isolates, $41(56.90 \%)$ isolates were MSSA and $31(43.05 \%)$ isolates were MRSA. The number and percentage of $S$. aureus clinical isolates (MSSA and MRSA) are shown in Figure 1.

Figure 1. Number and percentages of $S$. aureus clinical isolates (MSSA and MRSA)

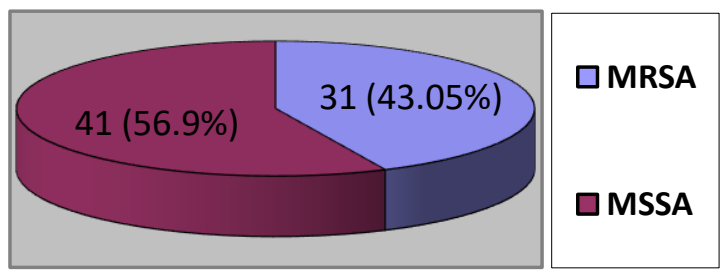

The MSSA isolates of the present study were highly resistant to penicillin (87.5\%), erythromycin $(61.1 \%)$ and clindamycin $(54.16 \%)$. On the contrary, lower resistance was shown to trimethoprim-sulfamethoxazole

$(19.44 \%)$, amikacin (16.66\%), linezolid (11.11\%) and chloramphenicol $(9.72 \%)$. The antibiotic sensitivity patterns of MSSA are shown in Table 1.

The MRSA isolates of the study were highly resistant to erythromycin (83.87\%), clindamycin $(80.64 \%)$, tetracycline $(58.06 \%)$ and ciprofloxacin $(48.38 \%)$. Lower resistance was manifested by trimethoprim-sulfamethoxazole $(35.48 \%)$, amikacin $(29.03 \%)$, linezolid $(22.58 \%)$ and chloramphenicol (16.12\%) in MRSA isolates. The antibiotic sensitivity patterns of MRSA are shown in Table 2.

Inducible Clindamycin Resistance of MSSA and MRSA isolates Of the 41 MSSA isolates inducible clindamycin resistance $\left(\mathrm{MLS}_{\mathrm{B}} \mathrm{i}\right.$ phenotype) was detected in $5(12.10 \%)$ of the isolates and of the 31 MRSA isolates, MLSB i phenotype was detected in $5(16.10 \%)$ isolates. The number and the percentage of MLS $\mathrm{B}_{\mathrm{B}} \mathrm{i}, \mathrm{MLS}_{\mathrm{B}}$ $\mathrm{c}$ and the $\mathrm{MS}_{\mathrm{B}}$ phenotypes of the MSSA and the MRSA isolates are shown in Table 3.
Table 1: The antibiotic sensitivity pattern of MSSA

\begin{tabular}{|c|c|c|c|}
\hline Antibiotic & $\begin{array}{l}\text { Sensitive } \\
\text { Number } \\
\text { and the } \\
\text { Percentage } \\
(\%)\end{array}$ & $\begin{array}{c}\text { Resistant } \\
\text { Number and } \\
\text { the } \\
\text { Percentage } \\
(\%)\end{array}$ & $\begin{array}{c}\text { Intermediate } \\
\text { Number and } \\
\text { the } \\
\text { Percentage } \\
(\%)\end{array}$ \\
\hline Cefoxitin & $\begin{array}{c}41 \\
(56.90 \%)\end{array}$ & $\begin{array}{c}31 \\
(43.05 \%)\end{array}$ & \\
\hline $\begin{array}{l}\text { Trimethoprim/ } \\
\text { sulfamethoxaz } \\
\text { ole }\end{array}$ & $\begin{array}{c}58 \\
(80.50 \%)\end{array}$ & $\begin{array}{c}14 \\
(19.44 \%)\end{array}$ & \\
\hline Erythromycin & $\begin{array}{c}25 \\
(34.72 \%)\end{array}$ & $\begin{array}{c}44 \\
(61.11 \%)\end{array}$ & $\begin{array}{c}3 \\
(4.16 \%)\end{array}$ \\
\hline Clindamycin & $\begin{array}{c}33 \\
(45.83 \%)\end{array}$ & $\begin{array}{c}39 \\
(54.16 \%)\end{array}$ & \\
\hline Ciprofloxacin & $\begin{array}{c}35 \\
(48.61 \%) \\
\end{array}$ & $\begin{array}{c}27 \\
(37.50 \%)\end{array}$ & $\begin{array}{c}10 \\
(13.80 \%)\end{array}$ \\
\hline Gentamycin & $\begin{array}{c}55 \\
(76.38 \%) \\
\end{array}$ & $\begin{array}{c}17 \\
(23.61 \%) \\
\end{array}$ & \\
\hline Amikacin & $\begin{array}{c}59 \\
(81.94 \%)\end{array}$ & $\begin{array}{c}12 \\
(16.66 \%)\end{array}$ & $\begin{array}{c}1 \\
(1.38 \%)\end{array}$ \\
\hline Linezolid & $\begin{array}{c}64 \\
(88.88 \%)\end{array}$ & $\begin{array}{c}8 \\
(11.11 \%)\end{array}$ & \\
\hline $\begin{array}{l}\text { Chlorampheni } \\
\text { col }\end{array}$ & $\begin{array}{c}65 \\
(90.27 \%)\end{array}$ & $\begin{array}{c}7 \\
(9.72 \%)\end{array}$ & \\
\hline Tetracycline & $\begin{array}{c}50 \\
(69.44 \%)\end{array}$ & $\begin{array}{c}20 \\
(27.77 \%)\end{array}$ & $\begin{array}{c}2 \\
(2.77 \%)\end{array}$ \\
\hline Penicillin & $\begin{array}{c}9 \\
(12.50 \%)\end{array}$ & $\begin{array}{c}63 \\
(87.50 \%)\end{array}$ & \\
\hline
\end{tabular}

MICs of Vancomycin in MRSA isolates Minimum inhibitory concentrations of vancomycin to the isolates of MRSA ranged from $0.25 \mu \mathrm{g} / \mathrm{ml}$ to $2 \mu \mathrm{g} / \mathrm{ml}$. The vancomycin MICs of the MRSA isolates are shown in Table 4.

The number of isolates within the MIC of $\leq$ $1 \mu \mathrm{g} / \mathrm{ml}$ was 21 and the number of isolates within the $\mathrm{MIC}$ of $1<\mathrm{MIC} \leq 2 \mu \mathrm{g} / \mathrm{ml}$ was 10 .

\section{Discussion}

Staphylococcus aureus is an adaptable pathogen, which may be responsible for causing community acquired as well as nosocomial infections[19]. Despite the years of efforts to develop the new antibiotics for the eradication of MRSA, it has established itself as the commonest cause of skin and soft tissue infections[20,21].

The isolation rate of MRSA in the present study was $43.5 \%$. A study that was conducted at a Tertiary Care Hospital in Bangalore India, had shown that the isolation rate of MRSA ranged from $29 \%$ to $39.5 \%$ and another study conducted in Iran the isolation rate of MRSA was 35\%[22]. A study which was conducted at the National Hospital of Sri Lanka had identified that $86 \%$ of the $S$. aureus isolates from wound curettings were as MRSA[28]. 
Table 2: The antibiotic sensitivity pattern of MRSA

\begin{tabular}{|c|c|c|c|}
\hline Antibiotic & $\begin{array}{l}\text { Sensitive } \\
\text { Number } \\
\text { and the } \\
\text { Percentage } \\
(\%)\end{array}$ & $\begin{array}{l}\text { Resistant } \\
\text { Number } \\
\text { and the } \\
\text { Percentage } \\
(\%)\end{array}$ & $\begin{array}{c}\text { Intermediate } \\
\text { Number and } \\
\text { the } \\
\text { Percentage } \\
(\%)\end{array}$ \\
\hline Cefoxitin & $\begin{array}{c}0 \\
(0 \%)\end{array}$ & $\begin{array}{c}31 \\
(100 \%)\end{array}$ & \\
\hline $\begin{array}{l}\text { Trimethoprim / } \\
\text { sulfamethoxazo } \\
\text { le }\end{array}$ & $\begin{array}{c}20 \\
(64.51 \%)\end{array}$ & $\begin{array}{c}11 \\
(35.48 \%)\end{array}$ & \\
\hline Erythromycin & $\begin{array}{c}4 \\
(12.90 \%)\end{array}$ & $\begin{array}{c}26 \\
(83.87 \%)\end{array}$ & $\begin{array}{c}1 \\
(3.22 \%)\end{array}$ \\
\hline Clindamycin & $\begin{array}{c}6 \\
(19.35 \%) \\
\end{array}$ & $\begin{array}{c}25 \\
(80.64 \%)\end{array}$ & \\
\hline Ciprofloxacin & $\begin{array}{c}13 \\
(41.93 \%)\end{array}$ & $\begin{array}{c}15 \\
(48.38 \%)\end{array}$ & $\begin{array}{c}3 \\
(9.67 \%)\end{array}$ \\
\hline Gentamycin & $\begin{array}{c}18 \\
(58.06 \%)\end{array}$ & $\begin{array}{c}13 \\
(41.93 \%)\end{array}$ & \\
\hline Amikacin & $\begin{array}{c}21 \\
(67.74 \%)\end{array}$ & $\begin{array}{c}9 \\
(29.03 \%) \\
\end{array}$ & $\begin{array}{c}1 \\
(3.22 \%)\end{array}$ \\
\hline Linezolid & $\begin{array}{c}24 \\
(77.41 \%)\end{array}$ & $\begin{array}{c}7 \\
(22.58 \%)\end{array}$ & \\
\hline $\begin{array}{l}\text { Chloramphenic } \\
\text { ol }\end{array}$ & $\begin{array}{c}26 \\
(83.87 \%) \\
\end{array}$ & $\begin{array}{c}5 \\
(16.12 \%) \\
\end{array}$ & \\
\hline Tetracycline & $\begin{array}{c}12 \\
(38.70 \%)\end{array}$ & $\begin{array}{c}18 \\
(58.06 \%)\end{array}$ & $\begin{array}{c}1 \\
(3.22 \%)\end{array}$ \\
\hline Penicillin & $\begin{array}{c}0 \\
(0 \%)\end{array}$ & $\begin{array}{c}31 \\
(100 \%)\end{array}$ & \\
\hline
\end{tabular}

Table 3. The number and the percentage of $M_{B S} i, M_{B} S_{B} c$ and the MS B phenotypes of the MSSA and the MRSA isolates

\begin{tabular}{|l|c|c|c|}
\hline $\begin{array}{l}\text { Number } \\
\text { of isolates }\end{array}$ & $\begin{array}{c}\text { MLS } \mathrm{B} \\
\text { Number } \\
\text { and } \\
\text { Percentage } \\
\%\end{array}$ & $\begin{array}{c}\text { MLS } \\
\text { Number } \\
\text { and } \\
\text { Percentage } \\
\%\end{array}$ & $\begin{array}{c}\text { MS } \\
\text { Number } \\
\text { and } \\
\text { Percentage } \\
\%\end{array}$ \\
\hline $\begin{array}{l}\text { MSSA } \\
(41)\end{array}$ & 5 & 13 & 5 \\
$(12.10 \%)$ & $(31.70 \%)$ & $(12.10 \%)$ \\
\hline $\begin{array}{l}\text { MRSA } \\
(31)\end{array}$ & 5 & 25 & 1 \\
$(16.1 \%)$ & $(80.6 \%)$ & $(3.2 \%)$ \\
\hline Total & 10 & 38 & 6 \\
$(13.8 \%)$ & $(52.7 \%)$ & $(8.3 \%)$ \\
\hline
\end{tabular}

The difference in the prevalence of MRSA among different studies may be due to difference in the location and time period of the study. The prevalence of MRSA may differ from one hospital to another hospital, depending upon the types of the patients it receives, infection control measures of the hospital and the health care workers. If the hospital is a referral center then the prevalence of the MRSA among the patients may be very high, as the chance of getting antimicrobial therapy before reaching the referral center is very high and due to selective pressure the bacteria may acquire drug resistance.
Table 4. The vancomycin MICs of the MRSA isolates

\begin{tabular}{|c|c|}
\hline $\begin{array}{c}\text { MIC range } \\
(\mu \mathrm{g} / \mathrm{ml})\end{array}$ & $\begin{array}{c}\text { MRSA } \\
\text { Number and the Percentage } \\
(\%) \text { of isolates }\end{array}$ \\
\hline$\leq 0.25$ & $0(0 \%)$ \\
\hline$\leq 0.38$ & $1(3.2 \%)$ \\
\hline$\leq 0.75$ & $2(6.4 \%)$ \\
\hline$\leq 0.5$ & $2(6.4 \%)$ \\
\hline$\leq 1$ & $16(51.61 \%)$ \\
\hline$\leq 1.5$ & $9(29.0 \%)$ \\
\hline$\leq 2$ & $1(3.2 \%)$ \\
\hline
\end{tabular}

Healthcare workers may be not only the important source of transmission of MRSA to patients or among patients or to the community[23]. Strict implementation of hand hygiene and decolonization of the MRSA carriers will be helpful to control the transmission of MRSA[11]. In addition, maintaining proper (environmental as well as personal) infection control measures in the hospital, among healthcare workers and patients will be more beneficial[24]. Due to the availability of limited treatment options for infections caused by MRSA, the treatment of such infections is often difficult leading to prolonged hospital stay and longer course along with higher cost of treatment sometimes leading to treatment failure resulting into fatal outcome[23].

Further, the higher rate of isolation of MRSA from clinical specimens of patients suggests that more attention to be given for infection control and surveillance, which may increase the overall infection control cost in the hospital[25].

The MRSA isolates of the present study had shown a high level of resistance to commonly used anti-staphylococcal antibiotics such as erythromycin (84\%), clindamycin (81\%), tetracycline (55\%) and ciprofloxacin (48\%). This was higher than levels of resistance described in earlier studies conducted in Sri Lanka[28].

Multidrug-resistant strains limit the therapeutic options, creating an economic and social burden to the healthcare system. Horizontal gene transfer in the hospital setting is responsible for disseminating antibiotic resistant determinants[26]. Therefore, the determination of accurate antibiotic susceptibility pattern is very important in the clinical care of bacterial 
infections, especially in organisms that possess acquired resistance mechanisms. At the same time careful consideration should be given when deciding how to interpret phenotypic susceptibility data [27,28]. In Sri Lanka, many laboratories have adopted CLSI guidelines as a basis for interpreting their susceptibility data.

In the present study, inducible resistance to clindamycin was present in MSSA (12\%) and the MRSA (16\%) isolates. In our study, the occurrence of inducible clindamycin resistance was not significantly different among the MSSA and MRSA isolates. However, differentiation of inducible clindamycin resistant phenotypes from others is crucial for therapeutic implication of clindamycin. As use of clindamycin for treatment of the infections caused by such bacteria may result into treatment failure, clindamycin should not be used for treatment of such infections; rather it should be used only for the treatment of the infections caused by bacteria, which are negative for inducible clindamycin resistance[5]. Clindamycin susceptible strains, which are erythromycin resistant, may show inducible clindamycin resistance ( $D$-test positive) and it has been suggested that inducible clindamycin resistant strains should be reported as clindamycin resistant[29]. Avoiding the use of clindamycin for the treatment of infections caused by erythromycin resistant strains also omits the chances of treatment failure[30].

In the present study, no strains of MRSA were found to be vancomycin resistant or vancomycin intermediate sensitive and the minimum inhibitory concentrations of vancomycin of the MRSA isolates ranged from $0.25 \mu \mathrm{g} / \mathrm{ml}$ to 2 $\mu \mathrm{g} / \mathrm{ml}$. A study conducted in Nepal [27], showed that there were four reported cases of VISA, with MIC of vancomycin ranging from $0.5 \mu \mathrm{g} / \mathrm{ml}$ to 4 $\mu \mathrm{g} / \mathrm{ml}[1]$. The discrepancy seen in results of different studies conducted in different parts in the world may be because of the involvement of the patients with previous history of exposure to vancomycin in some studies. No VRSA has yet been reported from Sri Lanka, but one isolate of VISA was reported in 2003[11]. Decreased susceptibility of $S$. aureus to vancomycin was reported first from Japan in 1997[1,32] and the first strain of VRSA was isolated in 2002 from Michigan, USA[1,33]. Since then the VISA and VRSA have been reported frequently by many researchers[1,27,31,34].

The mechanism behind the resistance of Staphylococcus aureus to vancomycin may be the thickening of cell wall[1,31-33]. In addition; prior exposure to vancomycin increases the chances of the isolation of the strains of Staphylococcus aureus with reduced susceptibility and the reason for emergence of VRSA/VISA may be the selective pressure due to the haphazard use of the antibiotics (vancomycin)[1,27]. The morbidity and mortality due to infection caused by VRSA are very high because of limited treatment options available[1,31]. At present when the infections due to MRSA have become a serious public health concern; the development and rapid spread of resistance of $S$. aureus to the reserve drug (vancomycin) is very fearsome and immediate actions should to be taken by the responsible authorities to halt it[31,34]. There is increasing trend of development of drug resistance among the micro-organisms due to the inappropriate use of antibiotics and this condition is more critical in developing countries[1]. To prevent the situation of the drug resistance from worsening; the use of antibiotic for the treatment of the patients should be based on culture and sensitivity reports[34].

\section{Conclusions}

In the present study, the rate of isolation of MRSA among the isolates of $S$. aureus was high and it was $43 \%$. The MIC of vancomycin for MRSA was found to be lower in comparison to similar other studies conducted in other countries. None of the MRSA isolates were found to be vancomycin-intermediate sensitive or vancomycin-resistant and vancomycin can still be used as the drug of choice for treatment of infections caused by MRSA. The MRSA isolates of the present study were resistant to multiple antibiotics. Therefore, proper antibiotic stewardship programs, adherence to infection control measures and health education programs will be necessary in the prevention and transmission of multi-drug resistance pathogens.

\section{References}

1. Datta P, Gulati N, Singla N, Rani Vasdeva $\mathrm{H}$, Bala K, Chander J, et al. Evaluation of various methods for the detection of meticillin-resistant Staphylococcus aureus strains and susceptibility patterns. J Med Microbiol. 2011 Nov;60(Pt 11):1613-6. doi: 10.1099/jmm.0.032219-0

2. Chambers HF. Methicillin resistance in staphylococci: molecular and biochemical basis and clinical implications. Clin Microbiol Rev. 1997 Oct;10(4):781-91. https://www.ncbi.nlm.nih.gov/pubmed/93 36672 
3. Chambers HF. Methicillin-resistant staphylococci. Clin Microbiol Rev. 1988 Apr;1(2):173-86.

doi: $10.1128 / \mathrm{cmr} \cdot 1.2 .173$

4. Chambers HF, Deleo FR. Waves of resistance: staphylococcus aureus in the antibiotic era. Nat Rev Microbiol. 2009 Sep;7(9):629-41.

doi: 10.1038/nrmicro2200

5. Prabhu K, Rao S, Rao V. andV. Rao, "Inducible clindamycin resistance in Staphylococcus aureus isolated from clinical samples. J Lab Physicians. 2011 Jan;3(1):25-7. doi: 10.4103/0974-2727.78558

6. Kshetry AO, Pant ND, Bhandari R, Khatri $\mathrm{S}$, Shrestha KL, Upadhaya SK, et al. Minimum inhibitory concentration of vancomycin to methicillin resistant Staphylococcus aureus isolated from different clinical samples at a tertiary care hospital in Nepal. Antimicrob Resist Infect Control. 2016 Jul;5(1):27. doi: 10.1186/s13756-016-0126-3

7. Baddour MM, Abuelkheir MM, Fatani AJ. Trends in antibiotic susceptibility patterns and epidemiology of MRSA isolates from several hospitals in Riyadh, Saudi Arabia. Ann Clin Microbiol Antimicrob. 2006 Dec;5(1):30. doi: 10.1186/1476-0711-5-30

8. Weerakoon W, Atukorala SD, Gamage DS, Wijeratne M. Staphylococcus aureus with reduced susceptibility to vancomycin. Ceylon Med J. 2003 Jun;48(2):58-9. https://www.ncbi.nlm.nih.gov/pubmed/12 971212

9. Abeygoonawardena $\mathrm{H}$, Navaratne $\mathrm{V}$, Balasuriya A, Gunawardane M. MIC of Vancomycin in S. aureus isolates in a selected community in Sri Lanka. Australian Journal of Medical Science. 2015;36(3):76-9.

10. Koyama N, Inokoshi J, Tomoda H. Antiinfectious agents against MRSA. Molecules. 2012 Dec;18(1):204-24. doi: 10.3390/molecules 18010204

11. Rehm SJ. Staphylococcus aureus: the new adventures of a legendary pathogen. Cleve Clin J Med. 2008 Mar;75(3):177-80. doi: $10.3949 /$ ccjm.75.3.177

12. Torimiro N. Analysis of Beta-lactamase production and antibiotics resistance in Staphylococcus aureus strains. Journal of Infectious Diseases and Immunity. 2013;5(3):24-8. doi $10.5897 /$ JIDI2013.0118

13. Grundmann H, Aires-de-Sousa M, Boyce J, Tiemersma E. Emergence and resurgence of meticillin-resistant Staphylococcus aureus as a public-health threat. Lancet. 2006 Sep;368(9538):874-85. doi:10.1016/s0140-6736(06)68853-3

14. Ito $\mathrm{T}$, Katayama $\mathrm{Y}$, Asada $\mathrm{K}$, Mori $\mathrm{N}$, Tsutsumimoto $\mathrm{K}$, Tiensasitorn $\mathrm{C}$, et al. Structural comparison of three types of staphylococcal cassette chromosome mec integrated in the chromosome in methicillinresistant Staphylococcus aureus. Antimicrob Agents Chemother. 2001 May;45(5):132336. doi:10.1128/AAC.45.5.1323-1336.2001

15. Johnson AP, "Methicillin-resistant Staphylococcus aureus: the European landscape," Journal of Antimicrobial Chemotherapy,vol. 66, no. S4, Article ID dkr076,pp.iv43-iv48, 2011. https://doi.org/10.1093/jac/dkr076.

16. Al-Zoubi MS, Al-Tayyar IA, Hussein E, Jabali AA, Khudairat S. Antimicrobial susceptibility pattern of Staphylococcus aureus isolated from clinical specimens in Northern area of Jordan. Iran J Microbiol. 2015Oct;7(5):265-72. doi: 10.4103/JLP.JLP_122_17

17. Tebelay D, Adane B. Prevalence and antimicrobial susceptibility pattern of methicillin resistant Staphylococcus aureus isolated from clinical samples at Yekatit 12 Hospital Medical College, Addis Ababa, Ethiopia. BMC Infectious Diseases. 2016. 16.10.1186/s12879-016-1742-5.

18. Papa R, Artini M, Cellini A, Tilotta M, Galano E, Pucci P, et al. A new antiinfective strategy to reduce the spreading of antibiotic resistance by the action on adhesion-mediated virulence factors in Staphylococcus aureus. Microb Pathog. 2013 Oct;63:44-53. http://dx.doi.org/10.1016/j.micpath.2013.0 5.003

19. Tisinger CK. Empowering your patients in the fight against methicillin-resistant Staphylococcus aureus. J Am Acad Nurse Pract. 2008 Apr;20(4):204-11.

20. Terp S, Krishnadasan A, Bowen W, Joo J, Furoy D, Chan J, et al. Introduction of rapid methicillin-resistant Staphylococcus aureus polymerase chain reaction testing and antibiotic selection among hospitalized patients with purulent skin infections. Clin Infect Dis. 2014 Apr;58(8):e129-32. doi: $10.1093 / \mathrm{cid} / \mathrm{ciu} 039$.

21. Kumburu HH, Sonda T, Mmbaga BT, Alifrangis M, Lund O, Kibiki G, et al. Patterns of infections, aetiological agents and antimicrobial resistance at a tertiary care hospital in northern Tanzania. Trop Med Int Health. 2017 Apr;22(4):454-64. doi:10.1111/tmi.12836

22. Pant ND, Sharma M. Carriage of methicillin resistant Staphylococcus aureus 
and awareness of infection control among health care workers working in intensive care unit of a hospital in Nepal. Braz $\mathbf{J}$ Infect Dis. 2016;20(2):218-9. doi:10.1016/j.bjid.2015.11.009

23. Amatya R, Devkota P, Gautam A. Reduced susceptibility to vancomycin in methicillin resistant Staphylococcus aureus: a time for action. Nepal Med Coll J. 2014;16(1):424.

https://www.ncbi.nlm.nih.gov/pubmed/25 799810

24. Nathwani D. Impact of methicillinresistant Staphylococcus aureus infections on key health economic outcomes: does reducing the length of hospital stay matter? J Antimicrob Chemother. 2003 May;51(90002 Suppl 2):ii37-44. doi: $10.1093 / \mathrm{jac} / \mathrm{dkg} 250$

25. Gitau W, Masika M, Musyoki M, Museve $B$ and Mutviri T. Antimicrobial susceptibility pattern of Staphylococcus aureus isolates from clinical specimens at Kenyatta National Hospital. BMC Research Notes 2018: 10 (2); 10-14. doi: 10.1186/s13104-018-3337-2

26. Adhikari R, Pant ND, Neupane S, Neupane M, Bhattarai R, Bhatta S, et al. Detection of Methicillin Resistant Staphylococcus aureus and Determination of Minimum Inhibitory Concentration of Vancomycin for Staphylococcus aureus Isolated from Pus/Wound Swab Samples of the Patients Attending a Tertiary Care Hospital in Kathmandu, Nepal. Can J Infect Dis Med Microbiol. 2017;2017:2191532. https://doi.org/10.1155/2017/2191532

27. Samaranayake W, Karunanayake L, Patabendige C. Characteristics of community acquired and hospital acquired methicillin resistant Staphylococcus aureus isolates in the National Hospital of Sri Lanka. Sri Lankan Journal of Infectious Diseases.2019;9(1):24-31.

http://doi.org/10.4038/sljid.v9i1.8229

28. Clinical and Laboratory Standards Institute. "Performance standards for antimicrobial susceptibility testing: twenty third informational supplement edition," CLSI Document M100-S23, CLSI,Wayne,Pa,USA,2013.

29. Fiebelkorn KR, Crawford SA, McElmeel ML, Jorgensen JH. Practical disk diffusion method for detection of inducible clindamycin resistance in Staphylococcus aureus and coagulase-negative staphylococci. J Clin Microbiol. 2003 Oct;41(10):4740-4. doi: $10.1128 / \mathrm{jcm} .41 .10 .4740-4744.2003$

30. Kshetry AO, Pant ND, Bhandari R, Khatri S, Shrestha KL, Upadhaya SK, et al. Minimum inhibitory concentration of vancomycin to methicillin resistant Staphylococcus aureus isolated from different clinical samples at a tertiary care hospital in Nepal. Antimicrob Resist Infect Control. 2016 Jul;5(1):27.

doi: 10.1186/s13756-016-0126-3

31. Kalil AC, Van Schooneveld TC, Fey PD, Rupp ME. Association between vancomycin minimum inhibitory concentration and mortality among patients with Staphylococcus aureus bloodstream infections: a systematic review and metaanalysis. JAMA. 2014 Oct;312(15):155264. doi: 10.1001/jama.2014.6364

32. Holland TL, Fowler VG Jr. Vancomycin minimum inhibitory concentration and outcome in patients with Staphylococcus aureus bacteremia: pearl or pellet? J Infect Dis. 2011 Aug;204(3):329-31. doi: 10.1093/infdis/jir275

33. Song JH, Hsueh PR, Chung DR, Ko KS, Kang CI, Peck KR, et al.; ANSORP Study Group. Spread of methicillin-resistant Staphylococcus aureus between the community and the hospitals in Asian countries: an ANSORP study. J Antimicrob Chemother. 2011 May;66(5):1061-9. doi: $10.1093 / \mathrm{jac} / \mathrm{dkr} 024$

34. Shrestha KL, Pant ND, Bhandari R, Khatri S, Shrestha B, Lekhak B. Re-emergence of the susceptibility of the Salmonella spp. isolated from blood samples to conventional first line antibiotics. Antimicrob Resist Infect Control. 2016 May;5(1):22. doi: 10.1186/s13756-016-0121-8 